Rev. Mus. Argentino Cienc. Nat., n.s.

7(1): 31-36, 2005

Buenos Aires, ISSN 1514-5158

\title{
Maniraptoran theropod ungual from the Marília Formation (Upper Cretaceous), Brazil
}

\author{
Fernando E. NOVAS ${ }^{1}$, Luiz Carlos BORGES RIBEIRO ${ }^{2,3}$ \& Ismar de SOUZA CARVALHO ${ }^{4}$
}

\begin{abstract}
${ }^{1}$ CONICET - Museo Argentino de Ciencias Naturales «Bernardino Rivadavia», Av. Angel Gallardo 470, Buenos Aires (1405), Argentina, E-mail: fernovas@yahoo.com.ar. ${ }^{2}$ Fundação Municipal de Ensino Superior de UberabaFUMESU/Centro de Pesquisas Paleontológicas L. I. Price. Av. Randolfo Borges Jr., $\mathrm{n}^{\circ} 1.250$. Universidade, 38.066-005, Uberaba- MG, Brazil, E-mail: cpplip@fumesu.br. ${ }^{3}$ Universidade de Uberaba-UNIUBE/Instituto de Formação de Educadores-Departamento de Biologia, Av. Nenê Sabino, $\mathrm{n}^{\circ}$ 1.801. Universitário, Uberaba-MG, 38.055-500, Brazil, E-mail: Icbrmg@terra.com.br. đUniversidade Federal do Rio de Janeiro, Departamento de Geologia, CCMN/IGEO. 21.949-900 Cidade Universitária-Ilha do Fundão, Rio de Janeiro-RJ, Brazil, E-mail: ismar@geologia.ufrj.br
\end{abstract}

\begin{abstract}
A new theropod record from the Marília Formation (Late Cretaceous, Minas Gerais, Brazil) is here described. It consists of an isolated manual ungual which exhibits derived maniraptoran features (e.g., presence of proximodorsal lip). The ungual distinguishes by a set of unique features (e.g., dorsoventrally low and proximodistally elongate profile in side view; block-like flexor tuberosity; proximal articular surface more dorsally oriented than in other theropods; cutting «keel» located distally on ventral surface) suggesting that the animal that produced it was a member of an unknown group of derived maniraptoran theropods, other than alvarezsaurids, deinonychosaurians and oviraptorosaurians already recorded in South America.
\end{abstract}

Key words. Theropoda, Maniraptora, Cretaceous, Marília Formation, Brazil.

The fossil record of Cretaceous theropod dinosaurs from Brazil is currently restricted to few incompletely known taxa. The Lower Cretaceous (?Albian) Santana Formation yielded the most complete and comprehensive theropod materials, including the spinosaurid Irritator challengeri (Martill et al., 1996; Kellner \& Campos, 1996; Sues et al., 2002), the compsognathid Mirischia asymmetrica (Naish et al., 2004), and the maniraptoriform Santanaraptor placidus

(Kellner, 1999, 2001). Also coming from the Santana Formation is a theropod sacrum originally described as possibly oviraptorosaurian (Frey \& Martill, 1995), but doubts have been rised about the correct assignment of this fragmentary specimen (Makovicky \& Sues, 1998).

The Upper Cretaceous theropod record from Brazil is scarce, the only named taxon is the abelisaurid Pycnonemosaurus nevesi, collected from Upper Cretaceous strata of Mato Grosso (Kellner \& Campos, 2002). Occurrences of theropod remains from Northern Brazil include some teeth, vertebrae and unguals from the São Luís Basin (Alcântara Formation, Cenomanian; Medeiros, 2001; Vilas Bôas et al., 1999). In regard with the Bauru Group, an inland basin partially covering the Brazilian states of São Paulo, Paraná, Mato Grosso do Sul, Minas Gerais and
Goiás (Fig. 1), has yielded a variety of saurischian remains (e.g., bones, teeth, eggs and eggshells; Bertini, 1996; Bertini et al., 1993; Magalhães Ribeiro \& Ribeiro, 1999; Magalhães Ribeiro, 2000). However, evidence on theropod dinosaurs is restricted to isolated teeth presumaly belong-ing to Carcharodontosauridae (collected from Serra da Galga; Kellner \& Campos, 1998), as well as teeth and skull fragments referred as to Abelisauridae indet. (Bertini, 1996).

In particular, excavations carried on at levels of the Marília Formation exposed at Serra do Veadinho, yielded abundant titanosaurid bones (Campos \& Kellner, 1999). Despite the frequency of well preserved sauropod remains, only some isolated theropod elements (mainly teeth, fragment of distal end of a femur, isolated pedal phalanges) have been found at the moment.

We aim to improve the meager theropod record of the Upper Cretaceous Marília Formation with the study of an isolated manual ungual, the morphology of which reveals that the taxonomic diversity of South American theropod faunas was higher than expected.

\section{Geology}

The Bauru Basin accumulated sediments of the Cretaceous Bauru Group, which is divided 
into three formations (from the bottom to top): Adamantina, Uberaba, and Marília (Fernandes \& Coimbra, 1996). From these units, the Marília Formation has offered the most comprehensive collection of dinosaur remains. It consists of a sequence of coarse to conglomeratic sandstones, mudstones and carbonate levels (Soares et al., 1980), corresponding to alluvial fans, braided flu-vial systems, alluvial plains and ephemeral lakes deposited under a hot and dry climate (Goldberg \& Garcia, 2000). The age of these deposits, based on charophyte and ostracod fossil records, is probably Maastrichtian (Dias-Brito et al., 2001).

\section{SYSTEMATIC PALEONTOLOGY}

\author{
Dinosauria Owen, 1852 \\ Theropoda Marsh, 1881 \\ Coelurosauria Huene, 1920 \\ Maniraptora Gauthier, 1986
}

\section{Gen. et sp. indet.}

Horizon and Locality: The fossil level corresponds to beds of the Serra da Galga Member of the Marília Formation (Maastrichtian, Upper Cretaceous). Serra do Veadinho (Lat. $19^{\circ} 43^{\prime}$ 25,5" S, Long. 47 44' 45,4" W), Peirópolis, Municipal-ity of Uberaba, Minas Gerais State, Brazil (Fig. 1).

Repository. CPPLIP (Centro de Pesquisas Paleontológicas «L.I.Price») number 659.

Description of specimen.The ungual (Figs. 2 \& 3 ) is well preserved, but lacks its distal extremity. It is $55 \mathrm{~mm}$ long at the outer curvature. Proximally, the bone is $13,7 \mathrm{~mm}$ deep and $8 \mathrm{~mm}$ wide. The size of the bone indicates that the animal that pro-duced the ungual was comparatively small and slender, probably reaching $2 \mathrm{~m}$ long, if compared with Oviraptor philoceratops, for example.

The ungual almost probably belongs to the manus because it is widely curved (approximately 95 degrees; curvature of the ungual was calcu-lated following the method described by Ostrom, 1969), transversely compressed, with slightly asymmetrically arranged colateral grooves, and most important, the proximal articular facet is dorsally oriented and bears a proximodorsal lip. This combination of features is absent in the-ropod pedal unguals, including the specialized one of digit 2 of deinonychosaurian theropods (e.g., Ostrom, 1969; Novas \& Pol, 2005). We ten-tatively interpret the ungual as corresponding to either manual digits II or III because of its de-gree of curvature and presence of proximodorsal lip (frenquently present in digits 2 and 3 of maniraptoran theropods). The ungual shows signs of a slight assymmetry: proximally, the left articular facet is more reduced than the right one, as well as the left colateral groove is located slightly below with respect to the right one. Comparing with the assymmetrical manual ungual of digit I of Megaraptor (Novas, 1998; Calvo et al., 2004), we tentatively interpret the ungual from Brazil as belonging to the right hand.

The ungual is elongate, dorsoventrally low, and sharply pointed in side view. The proximal articular facet bears a strong vertical ridge, and it is clearly delineated from adjacent surfaces. This is rectangular in shape, with the right facet (presumably the outer one) larger than the left (i.e., the inner one). This possibly reflects an assymmetrically arranged distal gynglimoid of the corresponding penultimate phalanx. A transversely wide lip is present on the proximodorsal margin of the ungual. The flexor tubercle is adjacent to the ventral border of the articular facet. It is block-like, ventrally flat and slightly rug-ose. The proximal surface of the tuberosity is smooth and «saddle-shaped» (i.e., transversely convex and slightly concave dorsoventrally).

Deeply excavated grooves are present on both left (i.e., medial) and right (i.e., lateral) surfaces, extending from the base of the proximal articu-lar facet to the distal extremity of the phalanx. Albeit the medial groove is dorsoventrally nar-rower than the lateral one, they are almost sym-metrically situated near the ventral edge of un-gual. The medial groove bears some vascular channels spreading almost tangentially towards the proximal end of the bone. Besides, the distal extremity of ungual exhibits, on both sides, some slight, crescent-shaped marks of unknown ana-tomical significance (Fig. 2, cm).

Except for its distal third, the ventral surface of ungual is flat and clearly distinguished from the sides of the bone through sharp edges. The ventral surface bears longitudinal striations and some tiny foramina situated approximately at mid -length of ungual. Notably, the distal third of the ventral surface forms a sharp cutting edge or «keel», proximally preceeded by a conspicu-ous elliptical foramen.

In cross section, the ungual has a roughly «8shaped» contour, a pattern that keeps at different levels even close to its distal extremity.

Comparisons and discussion. None of the currently theropod lineages recorded in the Cretaceous of South America (e.g., Abelisauroidea, Megaraptor namunhuaiquii, Spinosauridae, Alvarezsauridae; Carrano et al., 2002; Coria et al., 2002; Charig \& Milner, 1997; Novas, 1996, 1997, 1998; Calvo et al., 2004) exhibit the combination of features as described for the ungual from Brazil. 


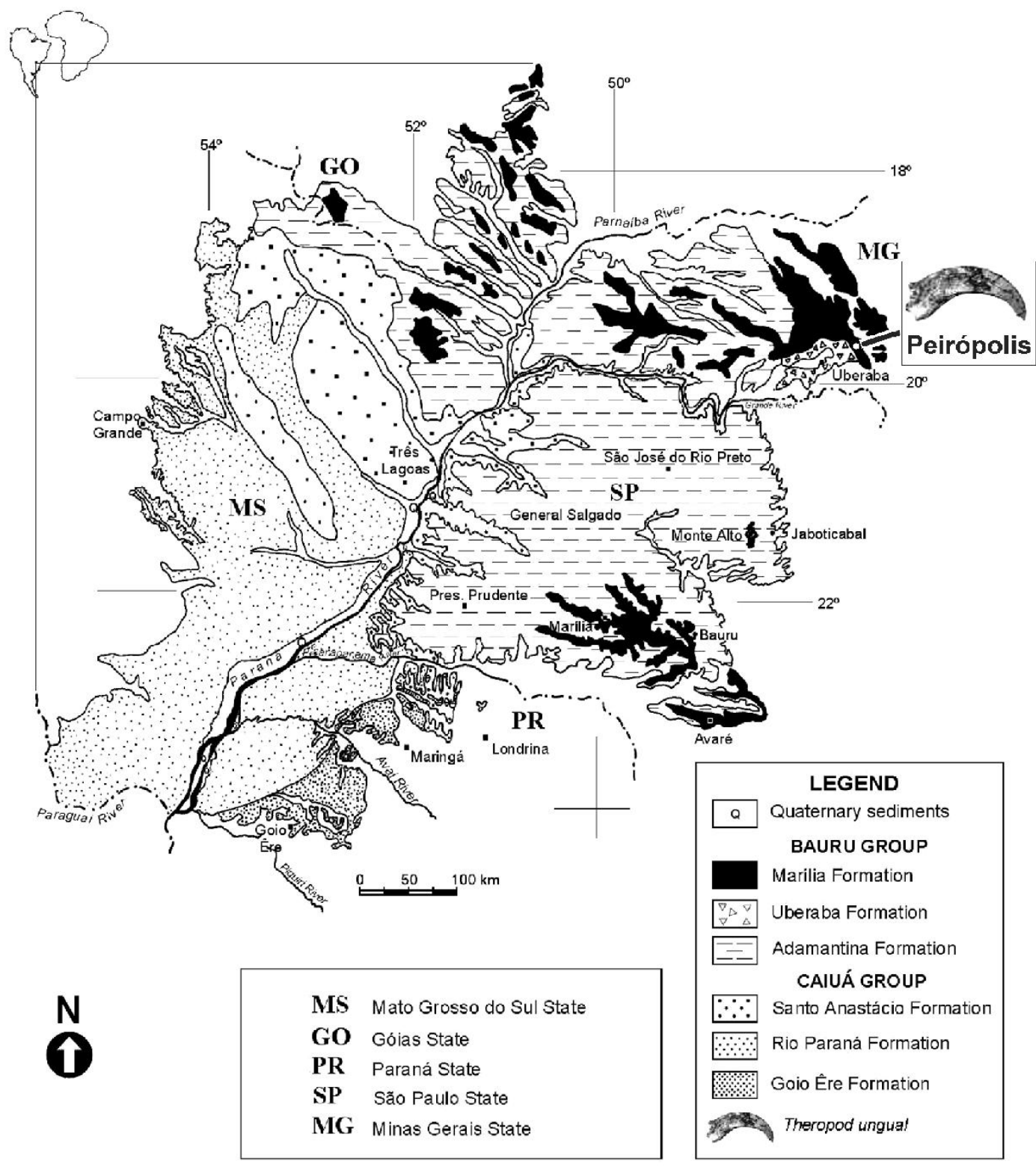

Fig. 1. Geological map of the Cretaceous Baurú Basin, Brazil, indicating fossil locality (Peirópolis).

On the contrary, the set of characters described above are only documented in a restrictive group of derived maniraptoran theropods, including oviraptorosaurs, Microvenator celer, troodontids, dromaeosaurids, and birds (Rauhut, 2003). For example, ungual lips are pronounced among Elmisauridae (e.g., Chirostenotes, Elmisaurus) and in the basal oviraptorosaur Microvenator (Currie, 1990). Proximodorsal lips are also present in Troodontidae (Osmólska \& Barsbold, 1990), but not uniformly in all manual unguals.
Lips are also present in early birds, being Archaeopteryx an oustanding example (Wellnhofer, 1988, 1993). Also, manual unguals of digits II and III of Deinonychus (Ostrom, 1969) exhibit proximodorsal lips, although less developed than in the above mentioned taxa. In the therizinosauroid Alxasaurus a lip is present on the ungual of digit II (Russell \& Dong, 1993). Proximal lips are absent in manual unguals of Compsognathus (Ostrom, 1978) and Ornitholestes (Rauhut, 2003). 


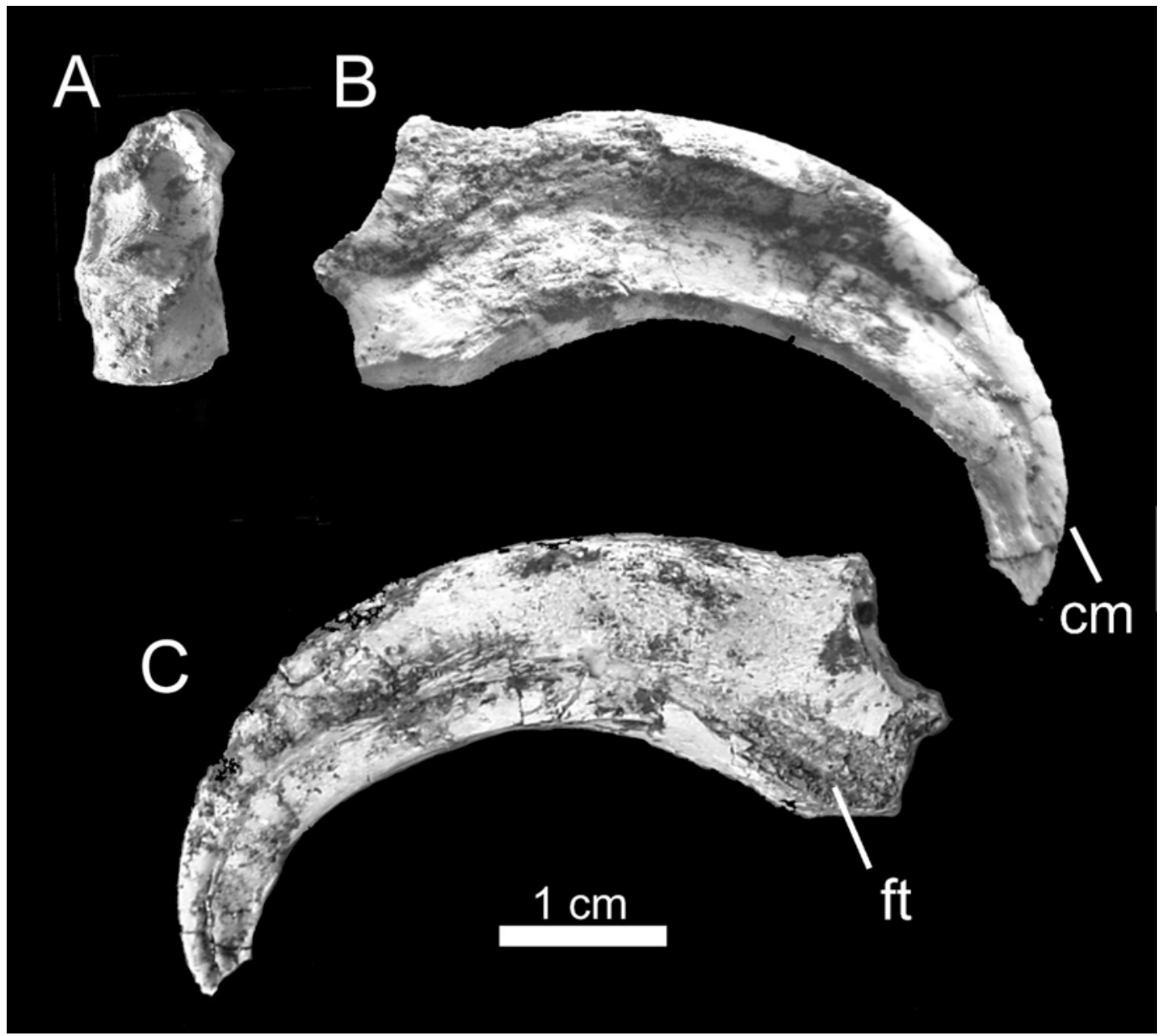

Fig. 2. Theropod ungual in $A$, proximal, $B$, right (lateral) view, and $C$, left (medial) views. Abbreviations: cm, crescent-shaped marks; ft, flexor tuber.

However, the flexor tuber in the Brazilian specimen is proportionally lower than the proximal articular surface, in contrast with troodontids, dromaeosaurids, and birds in which the height of the tuber exceeds half the height of the articular facet (Rauhut, 2003).

Following this, the specimen under study may represent a non-paravian maniraptoran more derived than Ornitholestes and Alvarezsauridae. The ungual from Brazil superficially resembles some oviraptorosaurs (e.g., elmisaurids) in being elongate and dorsoventrally depressed, but the absence of proximally bifurcated grooves, that characteristically occur in elmisaurids (Currie, 1990), dissmiss referal of the isolated ungual to this theropod clade.

In most theropods (e.g., Allosaurus, elmisaurids, deinonychosaurians, basal birds), the flexor tuberosity forms a ventrally convex promi- nence. In the ungual of Brazil, instead, the flexor tuberosity is shallower and is almost continuous with the ventral margin of ungual.

Several non-avian maniraptorans have been recorded in South America (e.g., Alvarezsauridae, possible Oviraptorosauria, Deinonychosauria; Novas, 1996, 1997; Novas \& Puerta, 1997; No-vas \& Agnolín, 2004; Novas \& Pol, 2005; Frank-furt \& Chiappe, 1999). Despite the apomorphic resemblances with maniraptorans, the ungual from Brazil lacks features seen in these groups: for example, alvarezsaurids retained only one large ungual on digit 1 (Novas, 1996), the mor-phology of which is quite different from that of the ungual here described. In reference with deinonychosaurians (i.e., troodontids and dromaeosaurids) they have strongly curved, tren-chant unguals on digits 1-3, that are easily dis-tinguished from the ungual from Brazil in its 


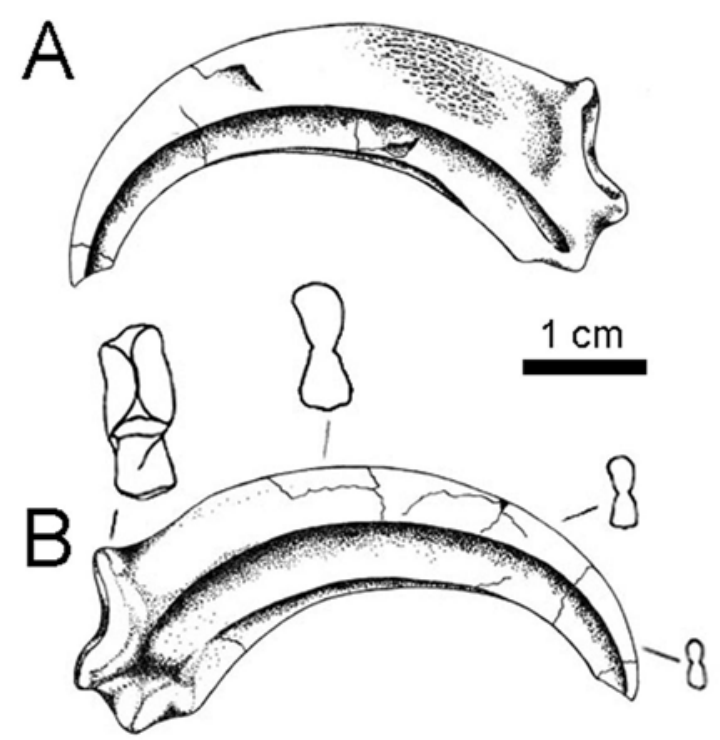

Fig. 3. Theropod ungual in A, left (medial) and B, right (lateral) views.

major degree of transverse compression and development of the ventral tuberosity. Finally, oviraptorosaurs (e.g., Clark et al., 1999) show unguals that, albeit less curved than in deinonychosaurs, are dorsoventrally deeper than in the ungual under study.

Moreover, several unique features, absent in the maniraptoran clades listed above, distinguish the ungual from Brazil: lateral profile dorsoventrally low and proximodistally elongate; block-like flexor tuberosity, almost continuous with the ungual ventral margin; proximal articular sur-face more dorsally oriented than in other the-ropods; proximodorsal lip transversely wide; and ventral surface flat but with a cutting «keel» lo-cated distally.

In sum, the bizarre features present in the studied ungual strongly suggest that it may represent a new example of derived maniraptorans unknown so far in this continent, not necessar-ily belonging to the currently recognized the-ropod clades.

\section{ACKNOWLEDGEMENTS}

We thank Leonardo Salgado for his valuable review of the manuscript. Financial support was provided by Fundação de Amparo à Pesquisa do Estado de Minas Gerais (FAPEMIG), Instituto Virtual de Paleontologia / Fundação Carlos
Chagas Filho de Amparo à Pesquisa do Estado do Rio de Janeiro (FAPERJ), Conselho Nacional de Desenvolvimento Científico e Tecnológico (CNPQ, grant $n^{\circ}$ 300571/03-8), and Agencia Nacional de Promoción Científica y Técnica (Buenos Aires, grant $n^{\circ}$ PICT 13803). The fossil analysed in this study was recovered by the field crew of the Fundação Municipal de Ensino Superior de Uberaba -Centro de Pesquisas Paleontológicas L. I. Price (Peirópolis, Uberaba). The drawings pre-sented in this paper were prepared by Ariel Milani Martine, Luiz Antonio Sampaio Ferro, and Marcelo Adorna Fernandes (UFRJ).

\section{BIBLIOGRAPHY}

Bertini, R.J. 1996. Evidencias de Abelisauridae (Carnosauria: Saurichia) do Neocretáceo da Bacia do Paraná. Simpósio Sobre o Cretáceo do Brasil, 4, Rio Claro, SP, 1996. UNESP. pp. 267-271.

Bertini, R.J., L.G. Marshall, M. Gayet \& P.M. Brito. 1993. Vertebrate faunas from the Adamantina and Marília formations (Upper Bauru Group, Late Cretaceous, Brazil) in their stratigraphic and paleobiogeographic context. Neues Jahr. Geol. und Paläont. Abh. 188(1): 71-101.

Calvo, J.O., J.D. Porfiri, C. Veralli, F.E. Novas, \& F. Poblete. 2004. Phylogenetic status of Megaraptor namunhuaiquii Novas based on a new specimen from Neuquén, Patagonia, Argentina. Ameghi-niana 41(4): 565-575.

Campos, D. \& A. Kellner. 1999. On some sauropod (Titanosauridae) pelves from the continental Cretaceous of Brazil. National Science Museum Monographs (Tokyo), 15: 143-166.

Carrano, M.T., S.D. Sampson, \& C.A. Forster. 2002. The osteology of Masiakasaurus knoplferi, a small abelisauroid (Dinosauria: Theropoda) from the Late Cretaceous of Madagascar. Jour. Vert. Paleont. 22(3): 510-534

Charig, A.J. \& A.C. Milner. 1997. Baryonyx walkeri, a fish-eating dinosaur from the Wealden of Surrey. Bull. Nat. Hist. Mus. London 53(1): 11-70.

Clark, J.M., M.A. Norell \& L.M. Chiappe. 1999. An oviraptorid skeleton from the Late Cretaceous of Ukhaa Tolgod, Mongolia, preserved in an avianlike brooding position over an oviraptorid nest. Amer. Mus. Nov. 3265: 1-36.

Coria, R.A., L.M. Chiappe \& L. Dingus. 2002. A new close relative of Carnotaurus sastrei Bonaparte 1985 (Theropoda: Abelisauridae) from the Late Cretaceous of Patagonia. Jour. Vert. Paleont. 22(2): 460-465.

Currie, P. 1990. Elmisauridae. 245-248. In: D.B. Weishampel, P. Dodson \& H. Osmolska (eds.) . The Dinosauria, University of California Press, Berkeley, $733 \mathrm{pp}$.

Dias-Brito, D., E.A. Musacchio, J.C. Castro, M.S.A.S. Maranhão, J.M. Suárez \& R. Rodrigues. 2001. Grupo Bauru: uma unidade continental do Cretáceo no Brasil - concepções baseadas em dados micro- 
paleontológicos, isotópicos e estratigráficos. Rev. Paleobiol. 20(1): 245-304.

Fernandes, L.A. \& A.M. Coimbra. 1996. A Bacia Bauru (Cretáceo Superior, Brasil). Anais Acad. Bras. Ciênc. 68(2): 195-205.

Frankfurt, N. G. \& L.M. Chiappe. 1999. A possible Oviraptorosaur from the Late Cretaceous of Northwestern Argentina. Jour. Vert. Paleont. 19(1): 101105.

Frey, E. \& D. Martill. 1995. A possible oviraptorosaurid theropod from the Santana Formation (Lower Cretaceous, ?Albian) of Brazil. N. Jb. Geol. Paläont. Mh. 7: 397-412.

Goldberg, K. \& A.J.V. Garcia. 2000. Palaeobiogeography of the Bauru Group, a dinosaur-bearing Cretaceous unit, northeastern Paraná Basin, Brazil. Cret. Res. 21: 241-254.

Kellner, A.W.A. 1999. Short note on a new dinosaur (Theropoda, Coelurosauria) from the Santana Formation (Romualdo Member, Albian) northeastern Brazil. Bol. Mus. Nac., Nova Serie, Rio de Janeiro 49: 1-8.

- 2001. New information on the theropod dinosaurs from the Santana Formation (Aptian-Albian), Araripe Basin, northeastern Brazil. Jour. Vert. Paleont. 21(Suppl. 3): 67A.

Kellner, A.W.A. \& D.d.A. Campos. 1996. First Early Cretaceous theropod dinosaur from Brazil. Neues Jahr. Geol. und Paläont. Abh. 199: 151-166.

- 1998. Review of cretaceous theropods and sauropods from Brazil. Jour. Vert. Paleont. 18(Suppl. 3): $55 \mathrm{~A}$

- 2002. On a theropod dinosaur (Abelisauria) from the continental Cretaceous of Brazil. Arquivos Mus.Nac.Rio de Janeiro 60(3): 163-170.

Magalhães Ribeiro, C.M. 2000. Microstructural analysis of dinosaur eggshells from Bauru Basin (Late Cretaceous), Minas Gerais, Brasil. First International Symposium on Dinosaur Eggs and Babies (Abstracts), pp. 117-121.

Magalhães Ribeiro, C.M. \& L.C.B. Ribeiro. 1999. Um ovo de dinossauro em sucessões fluviais da Formação Marília (Cretáceo Superior), em Peirópolis (Uberaba, Minas Gerais). Boletim de Resumos do $6^{\circ}$ Simpósio de Geologia do Sudeste, São Pedro, p. 76.

Makovicky, P.J. \& H.-D. Sues. 1998. Anatomy and phylogenetic relationships of the theropod dino-saur Microvenator celer from the Lower Creta-ceous of Montana. Amer. Mus. Nov. 3240: 1-27.

Martill, D.M., A.R.I. Cruickshank, E. Frey, P.G. Small \& M. Clarke. 1996. A new crested maniraptoran dinosaur from the Santana Formation (Lower Cretaceous) of Brazil. Jour. Geol. Soc., 153: 5-8.

Medeiros, M.A.A. 2001. A Laje do Coringa (Ilha do Cajual, Bacia de São Luís, Baía de São Marcos, MA): conteúdo fossilífero, bioestratinomia, diagênese e implicações na paleobiogeografia do Mesocretáceo do Nordeste brasileiro. Univ.Fed. Rio Grande do Sul. Tese de Doutorado. Programa de Pós-Graduação em Geociências, pp.1-107.
Naish, D., D.M. Martill \& E. Frey. 2004. Ecology, systematics and biogeographical relationships of dinosaurs, including a new theropod, from the Santana Formation (?Albian, Early Cretaceous) of Brazil. Hist. Biol. 2004: 1-14.

Novas, F. 1996. Alvarezsauridae, Cretaceous maniraptorans from Patagonia and Mongolia. Queensland Museum Memoirs 31: 320-351.

- 1997. Anatomy of Patagonykus puertai (Theropoda, Avialae, Alvarezsauridae), from the Late Cretaceous of Patagonia. Jour. Vert. Paleont. 17(1): 137166.

- $\quad$ 1998. Megaraptor namunhuaiquii gen. et sp. nov., a large-clawed, Late Cretaceous Theropod from Argentina. Jour. Vert. Paleont.18(1): 4-9.

Novas, F.E. \& F. Agnolín. 2004. Unquillosaurus ceibali Powell, a giant maniraptoran (Dinosauria, Theropoda) from the Late Cretaceous of Argen-tina. Rev. Mus. Arg. Cienc. Nat. «B.Rivadavia» 6(1): 61-66.

Novas, F. \& P. Puerta. 1997. New evidence concern-ing avian origins from the Late Cretaceous of Patagonia. Nature 387: 390-392.

Novas, F.E. \& D. Pol. 2005. New evidence on deinonychosaurian dinosaurs from the Late Cretaceous of Patagonia. Nature 433: 858-861.

Osmólska, H. \& R. Barsbold. 1990. Troodontidae. 259268. In: Weishampel, D.B., P. Dodson and H. Osmolska (eds.). The Dinosauria, University of California Press, Berkeley, 733 pp.

Ostrom, J.H. 1969. Osteology of Deinonychus antirrhopus, an unusual theropod from the Lower Cretaceous of Montana. Bull. Peabody Mus. Nat. Hist. 30: 1-165.

- $\quad$ 1978. The osteology of Compsognathus longipes Wagner. Zitteliana 4: 73-118.

Rauhut, O.W.M. 2003. The interrelationships and evolution of basal theropod dinosaurs. Spec. Pap. Palaeont. 69: 1-213.

Russell, D., \& Z. Dong. 1993. A nearly complete skeleton of a new troodontid dinosaur from the Early Cretaceous of the Ordos Basin, Inner Mongolia, People's Republic of China. Can. Journ. Earth Sci. 30: 2163-2173.

Soares, P.C., P.M.B. Landim, V.J. Fulfaro \& A.F. Sobreiro Neto. 1980. Ensaio de caracterização estratigráfica do Cretáceo no Estado de São Paulo: Grupo Bauru. Rev. Bras. Geociências 10(3): 177-185.

Sues, H.-D., E. Frey, D.M. Martill \& D.M. Scott. 2002. Irritator challangeri, a spinosaurid (Dinosauria: Theropoda) from the Lower Cretaceous of Brazil. Jour. Vert. Paleont. 22: 535-547.

Vilas Bôas, I., I.S. Carvalho, M.A. Medeiros, \& H. Pontes. 1999. Dentes de Carcharodontosaurus (Dinosauria, Tyrannosauridae) do Cenomaniano, Bacia de São Luís (Norte do Brasil). An. Acad. Bras. Ciênc. 71(4): 846-847.

Wellnhofer, P. 1988. Ein neues Exemplar von Archaeopteryx. Archaeopteryx 6: 1-30.

1993. Das siebte Exemplar von Archaeopteryx aus den Solnhofener Schichten. Archaeopteryx 11: 1-48. 